prohram dlia 1-4-kh klasiv zahalnoosvitnikh navchalnykh zakladiv" (2016). [On Enacting Amendments to Educational Programmes for the 14 Forms of General Education Institutions]. [Electronic resource]. Available at: https://mon.gov.ua/ua/osvita/ zagalna-serednya-osvita/navchalni-programi/ navchalni-programi-dlya-pochatkovoyi-shkoli [in Ukrainian].

3. Rostovskyi, O. Ya. (2011). Teoriia i metodyka muzychnoi osvity: Navch.-metod. Posibnyk [Theory and Methodology of Art Education: Study Guide]. Ternopil: Academic Book - Bohdan, 640 p. [in Ukrainian].

4. Savchenko, O. Ya. (2012). Novyi derzhstandart dlia pochatkovoi shkoly: vid zadumu do realizatsii
[New State Standard for Primary School: from Idea to Realization]. Pedagogical Newspaper, No.1 (210), p. 4. [in Ukrainian].

5. Strykhar, O. Y. (2013). Eksperymentalni doslidzhennia iz zastosuvannia pryntsypu intehratsii $\mathrm{v}$ navchanni muzychnomu mystetstvu ditei [Experimental Researches on Applying a Principle of Integration in Teaching Children Musical Art]. Journal of Cherkasy University. Series: Pedagogical Sciences. Scientific Journal, No.3 (256), 152 p. [in Ukrainian].

6. Cherkasov, V. F. (2016). Teoriia i metodyka muzychnoi osvity: navch. posibnyk [Theory and Methodology of Art Education: Textbook]. Series: Almamater. Kyiv: VTs “Akademiia”, 240 p. [in Ukrainian].

Стаття надійшла до редакції 04.01.2019

УДК $378.011 .3-051$

DOI:

Соломія Ілляш, кандидат психологічних наук, дочент кафедри педагогіки та методики початкової освіти Дрогобииького державного педагогічного університету імені Івана Франка

\title{
РОЗВИТОК ПРОФЕСІЙНОГО САМОРОЗУМІННЯ В ПРОЦЕСІ ПІДГОТОВКИ МАЙБУТНІХ УЧИТЕЛІВ
}

У статті досліджено проблему розвитку професійного саморозуміння в майбутніх учителів; проаналізовано психологічні аспекти проблеми саморозуміння; розглянуто основні підходи щооо вивчення та діагностики процесу розуміння; виокремлено суттєві ознаки та структурно-динамічні характеристики саморозуміння; розкрито зв 'язок професійно-педагогічної спрямованості і саморозуміння майбутніх учителів; визначено функиії та показники професійного саморозуміння; з 'ясовано способи впливу саморозуміння на успішність професійної діяльності майбутніх учителів початкової школи.

Ключові слова: самосвідомість; професійне саморозуміння; професійно-педагогічна спрямованість; професійно-педагогічна підготовка; майбутні вчителі; початкова школа; професійна діяльність.

Jim. 8.

Solomiya Illyash, Ph.D.(Psychology), Associate Professor of the Pedagogy and Methodology of Primary Education Department Drohobych Ivan Franko State Pedagogical University

\section{THE DEVELOPMENT OF PROFESSIONAL SELF-UNDERSTANDING IN THE PROCESS OF TRAINING OF FUTURE TEACHERS}

The problem of the development of the future teachers ' professional self-understanding is investigated in the article; it analyzes the psychological aspects of the problem of self-understanding and it establishes that a person does not understand herself at once; this ability develops gradually throughout life, under the influence of numerous social phenomena. The article reviews the main approaches to studying and diagnostics the process of understanding which scientists conditionally define as ,objective" and "subjective” ones. It is found out that the realization of the "objective" approach means a detailed study of the subject of understanding, its structural organization and internal regularities of the development. On the contrary, the "subjective" approach to the study of understanding is focused, first of all, on the study of mechanisms, the object of understanding is considered as a condition for the intellectual activity of the subject. The following features of self-understanding are singled out: depth, clarity and flexibility as well as some structural and dynamic characteristics of this personal formation. The article reveals the connection of professional pedagogical orientation and self-understanding of future teachers; it finds out that the concept of professional self-understanding is wider than the concept of pedagogical orientation. The concept of professional self-understanding includes the system of ideas about professional training, goals, tasks and results of professional self-improvement. The functions of self-understanding are singled out: inductive, cognitive and evaluative, regulatory. The indicators of professional self-understanding are determined. They are the motives which impel to 
self-understanding according to the criterion of its formation; the attitude to themselves and others; the presence of a realistic self-esteem according to the criterion of adequacy; the ability to be reflective and to make an internal dialogue, and others. The methods of the influence of self-understanding on the success of professional activity of future primary school teachers are determined.

Keywords: self-awareness; professional self-understanding; professional and pedagogical orientation; professional and pedagogical training; future teachers; primary school; professional activity.

П остановка проблеми. Модернізація та удосконалення системи освіти в Україні загострюють вимоги щодо якості вищої освіти та підготовки спеціалістів, критерієм якої є не стільки об’єм знань, умінь та навичок, скільки здатність приймати науково обгрунтовані і технологічно грамотні рішення, вільно орієнтуватися в інформаційному просторі, творчо мислити і вирішувати нестандартні професійні завдання, самостійно здобувати нові наукові знання, а також здатність до саморозуміння та саморозвитку в процесі професійної діяльності.

Сьогодення висуває особливі вимоги до рівня теоретико-практичної та психологічної підготовки майбутніх учителів. Особливо високими є вимоги до психологічної культури вчителя початкової школи. Адже він повинен не лише проводити урок, застосовуючи сучасні технології навчання, але й володіти знаннями про вікові, індивідуальні особливості та можливості учнів; своєчасно фіксувати i коригувати відхилення в інтелектуальному, особистісному, поведінковому розвитку учнів; вміти застосовувати різноманітні технології розв'язання конфліктних ситуацій; володіти навичками роботи з сім'єю проблемної дитини. Зазначені умови вимагають висувати на перший план проблему пошуку нових шляхів професійної підготовки майбутніх учителів початкової школи.

Нову стратегію підготовки студента майбутнього вчителя початкової школи вбачаємо у становленні його професійної самосвідомості та саморозуміння. Психологічну культуру майбутньої генерації педагогів розглядаємо важливою умовою зростання їх професіоналізму.

Аналіз основних досліджень і публікацій. Проблема професійного становлення розроблялася у численних дослідженнях, які можна узагальнити у наступні напрямки: 1) дослідження професійних “образів Я” і “Я-концепції” (В. Гарвей, Ш. Поттебаум, В. Кейт); 2) дослідження ролі самооцінки та самоставлення майбутнього вчителя (М. Розенберг, Т. Уайт, Р. Робертсон, У. Крейн, І. Паркер, Д. Бернс); 3) дослідження ролі педагогічної практики в професійній підготовці вчителя (Р. Гудін, Р. Мецнер, Е. Елсворс, Р. Харіс).

Вітчизняні психологи також вивчали проблему професійного становлення майбутніх учителів (Б.Г. Ананьєв, Л.С. Виготський, С.В. Васьківська, Н.Ф. Добринін, В.Н. Козієв, Н.Д. Левітов, О.М. Леонтьєв, В.Н. Мясищев, С.Л. Рубінштейн, В.П. Саврасов та ін.), вивчали мотивацію діяльності, професійно-педагогічну спрямованість особистості (С.А. Асаделіна, С.А. Зімчева, Н.В. Кузьміна, Ю.Н. Кулюткін, С.К. Матлін, Т.П. Маралова, Є.М. Нікірєєв, В.А. Сластьонін, Г.С. Сухобська, Т.А. Томілова, Р.М. Фатихова та iн.).

Дослідники роблять надзвичайно важливий висновок про те, що в програмах професійнопедагогічної підготовки студентів особливе місце має відводитися “погляду на себе”, тобто професійно-педагогічному саморозумінню, оскільки зміни самовизначень юнаків та дівчат майбутніх учителів - важливий аспект їхньої професійної соціалізації.

Аналіз наукової літератури засвідчує, що в психології самосвідомості повних, широко представлених досліджень проблеми саморозуміння на даний час немає. Існують окремі розробки, які знайшли своє відображення в деяких дослідженнях і зафіксовані в окремих психодіагностичних методиках, де саморозуміння представлено як один із алгоритмів методики самоставлення або тесту 3 оцінки рівня самоактуалізації особистості (Л.Я. Гозман, Ю.С. Альошина, М.В. Загіка, М.В. Кроз, Н.Ф. Каліна).

Мета статті - висвітлити психологічні аспекти розвитку професійного саморозуміння майбутніх учителів, визначити способи впливу саморозуміння на успішність професійної діяльності майбутніх учителів початкової школи.

Виклад основного матеріалу дослідження. Сучасна молода людина поставлена в такі суспільні умови, коли від їі активності, яка грунтується на розумінні себе в контексті життя, багато в чому залежить iї успішність. 3 одного боку, для повноцінного існування людина потребує розуміння i прийняття нового для неї навколишнього світу, а з іншого - вона стоїть перед “психологічним завданням” зрозуміти саму себе, прийняти себе в цьому світі, що сприятиме цілісному уявленню людини про себе. Це дозволить молодій людині виступати суб'єктом діяльності та спілкування, виявляти суб'єктивну активність. 
Юнацький вік $є$ періодом прийняття власних відповідальних рішень, які визначають все подальше життя людини: вибір професії і свого місця в житті, вибір сенсу життя, вироблення світогляду і життєвої позиції. Формування особистості в цьому віці визначається тими психологічними новоутвореннями періоду, які створюють основу для повноцінного особистісного становлення людини, здатної розв'язувати численні життєві проблеми самостійно і бути успішною в соціально значущій діяльності, легко адаптуватися, знаходити своє достойне місце, визначати свою позицію щодо умов суспільства, які швидко змінюються.

Для цього необхідно вивчати психологічні феномени, які, з одного боку, позначені в психологічній науці, але не знайшли належної уваги в дослідженнях, які стосуються проблеми соціального становлення і розвитку особистості молодої людини, а з іншого, дозволяють глибше зрозуміти характер процесів соціалізації та індивідуалізації, що сприяють розвитку людини.

Саморозуміння виникає у людини не відразу, а складається і розвивається поступово протягом життя під впливом численних соціальних явищ. У процесі соціалізації у юнаків та дівчат формується досвід розуміння своїх можливостей, необхідних для досягнення певних цілей. Виникнення i розвиток саморозуміння $\epsilon$ результатом необхідності оволодіння власною психікою, регулювання якою забезпечує нормальне функціонування людини як особистості, як члена суспільства і як представника певної професійної групи $[1,50]$.

Коротко зупинимося на аналізі такого важливого аспекту проблеми як професійне саморозуміння.

На нашу думку, навчання у вищому закладі освіти необхідно розглядати як процес, який дає студентам цілісний образ майбутньої професії та їхнього місця в ній, актуалізує у студентів рефлексію особистісних функцій щодо конкретних вимог професійної діяльності. Професійне саморозуміння визначається тим, що цілісний “образ Я” вчителя (майбутнього вчителя) вписується в загальну схему його ціннісних орієнтацій, пов'язаних з розумінням цілей своєї професійної діяльності і засобів, необхідних для їх конструктивного досягнення. В умовах навчання і виховання в педагогічному вузі професійне саморозуміння студента - це розуміння себе як майбутнього вчителя, як суб'єкта професійно-педагогічної підготовки.

Істотною ознакою саморозуміння, на наш погляд, буде не стільки знання, ставлення людини до самої себе, не стільки аналіз своїх думок, почуттів тощо, скільки проникнення в смислове існування, необхідне для того, щоб узгодити своє “я” 3 навколишнім реальним світом. Виокремлення цієї істотної ознаки дозволило нам розглянути i вивчити проблему розвитку саморозуміння, джерел, умов і чинників цього розвитку. Цьому буде сприяти визначення поняття саморозуміння та вивчення структурнодинамічних характеристик цього особистісного утворення.

На наш погляд, саморозуміння систематизує, ієрархізує уявлення про себе і викликані ними переживання. Можна виокремити такі ознаки саморозуміння: глибину, чіткість і гнучкість. Глибина - це осмисленість себе у всій схемі “ $Я$ ", чіткість - уявлення про себе, яке складається в певну систему внутрішнього “Я”, тобто є системною характеристикою “Я”. Чіткість розуміння себе визначає строгу диференціацію компонентів “Я”, коли зміни одного з них не так сильно впливають на інший. Глибина визначає ієрархію ціннісно-орієнтованої шкали, що складає внутрішню системність, а остання $є$ характеристикою чіткості. Системність визначає зв’язність, але не зчепленість, що не руйнує весь ланцюг ціннісно-орієнтованої шкали при критиці однієї з них. Глибина і чіткість розуміння себе можливі тільки при децентрації особистості, при внутрішньому діалозі. Глибина і чіткість приводять до ясності внутрішніх пріоритетів. Гнучкість виявляється в засобах для досягнення мети. У відповідь на вплив збоку людина змінює інструментальний склад своєї діяльності, зберігаючи внутрішню цілісність [4, 37].

Поверховість, нечіткість саморозуміння призводить до центрування особистості. Поверховість визначає беззахисність людини перед зовнішніми силами, що сприяє зверненню до психологічних захистів, які не вирішують проблему, а тільки вуалюють ії. При поверховому саморозумінні висвітлюються тільки очевидні ціннісно-орієнтаційні шкали, які мають зчепленість і підлягають ситуативності. Зміна ситуації приводить до глобальної критики ціннісноорієнтовану шкалу, що ускладнює саморегулятивну діяльність суб' єкта.

Професійне саморозуміння визначається тим, що цілісний образ “Я” вчителя (майбутнього вчителя) вписується в загальну схему його ціннісних орієнтацій, пов' язаних з розумінням цілей своєї професійної діяльності і засобів, необхідних для їх конструктивного досягнення.

Ми виходили 3 того, що в умовах навчання і виховання в педагогічному вузі професійне 
саморозуміння студента - це розуміння себе як майбутнього вчителя, як суб'єкта професійнопедагогічної підготовки.

Вивчення саморозуміння $\epsilon$ складною проблемою, оскільки людина важко усвідомлює смисл свого існування. Адже це вимагає іiі внутрішньої роботи, яка може здійснюватися на рівні рефлексії, аналізу своїх потреб, ідеалів, переконань, тощо.

Можна констатувати, що нині існують два основні підходи до дослідження і діагностики розуміння, які умовно Є.Ю. Савін позначив як “об” єктний” i “суб'єктний”. Реалізація першого підходу передбачає детальне дослідження предмета розуміння, його структурної організації та внутрішніх закономірностей розвитку. Сам же процес розуміння розглядається як ментальний акт проникнення в цю організацію або ж їі осягнення. Відповідно до цього рівень розуміння визначається тим, наскільки глибоко суб' єкт просунувся в осягненні об'єкта $[8,234]$.

Діагностика в рамках “об'єктного” підходу передбачає розробку системи завдань, які дозволяють визначити, якого саме рівня досяг суб'єкт в осягненні предметного змісту. Головним недоліком цього підходу Є.Ю. Савін вважає те, що недостатня увага приділяється тим психологічним механізмам, завдяки яким суб'єкт проникає в глибину об'єкта розуміння. На відміну від цього, “суб'єктний” підхід дослідження розуміння орієнтований насамперед на вивчення механізмів, при цьому об'єкт розуміння розглядається як умова для інтелектуальної діяльності суб' єкта [8, 235].

Розглядаючи особистість вчителя 3 позицій суб' єктного підходу, А.К. Маркова $[6,183]$ робить акцент на властивостях i якостях, що характеризують його як суб'єкт пізнання, професійної діяльності та спілкування. Як суб'єкт професійної діяльності, вчитель сам визначає іiі зміст, завдання і способи, будує діяльність та спілкування на педагогічних засадах. Побудова професійної підготовки вчителя 3 позиції “суб'єктного” підходу означає створення умов для постійної самореалізації.

Поняття професійної спрямованості розглядається як емоційно-ціннісне ставлення людини до професії, стійкий інтерес до неї, схильність займатися різними видами діяльності, в якій втілюється специфіка даної професії як узагальнене позитивне ставлення до своєї професії $[4,72]$.

Найбільш коректним, на наш погляд, $є$ визначення Т.П. Маралової: “...професійнопедагогічна спрямованість... - це стійка властивість особистості, що виражає загальну спрямованість в специфічному виді діяльності учительській праці, яка є по суті системою відношень індивіда до професії; до предмету, що викладається; до дітей і до себе як суб'єкта педагогічної діяльності” [ 5,48$]$.

Розглядаючи проблему зв'язку професійнопедагогічної спрямованості і саморозуміння майбутнього вчителя, необхідно виокремити два моменти:

1) розвиток відношень особистості, оскільки вони виявляються в діяльності, випереджає їх відображення в самосвідомості, самопізнанні та саморозумінні;

2) педагогічна спрямованість входить до професійного саморозуміння через систему самоставлень до професії, як професійна позиція $[5,52]$

Отже, професійне саморозуміння ширше від педагогічної спрямованості: до нього належить і система уявлень про професійну підготовку, цілі, завдання, i результати професійного самоудосконалення.

Виходячи 3 цього, професійним $є$ таке саморозуміння, складові феномени якого починають набувати професійного змісту, беручи участь у регуляції педагогічної діяльності, у процесі опосередкованої передачі смислів, цінностей, відношень у просторі педагогічної ситуації.

Будь-якій цілісній системі, у тому числі й педагогічній, властиві специфічні функції, які зумовлені природою iٓi компонентів, їх взаємозв'язками. Розвиток саморозуміння педагога детермінується актуалізацією особистісних функцій в конкретній педагогічній ситуації.

Н.I. Протасова виокремлює наступні функції саморозуміння педагога:

1) спонукальну, яка виявляється в пошуку соціальної позиції, сенсу педагогічної діяльності;

2) пізнавально-оцінну-в розумінні професійних атрибутів своєї діяльності, що передбачає засвоєння психологічних знань, методів та способів їх одержання, формування оцінного ставлення до себе та інших людей;

3) регулятивну - в утриманні себе в рамках педагогічної ситуації. Комплексна реалізація вказаних функцій веде до саморозвитку особистості загалом [7, 137].

В основі саморозуміння себе як професіонала лежить професійна самосвідомість. Є.О. Клімов виокремлює такі компоненти самосвідомості професіонала:

1) усвідомлення своєї приналежності до певної професійної спільноти; 
2) думка про міру власної відповідності становлення, деякі 3 них, зокрема досвід професійним еталонам;

3) знання людини про міру її покликання в професійній групі;

4) знання про свої сильні та слабкі сторони, шляхи удосконалення, вірогідні зони успіхів та невдач; уявлення про себе та свою роботу в майбутньому;

5) співвіднесеність професійної діяльності і “Яобразу” [2, 95 - 102]. Виокремлені компоненти стосуються лише когнітивної сфери і не заторкують всі інші.

Н.I. Протасова, грунтуючись на теоретичних доробках, що стосуються проблеми професійного становлення, виокремлює наступні компоненти професійного саморозуміння: мотиваційноціннісний, змістовно-процесуальний та емоційновольовий. Ці компоненти знаходяться у системних зв'язках і мають свої специфічні функції [7, 138].

На думку дослідниці показником професійного саморозуміння $\epsilon$ :

- мотиви, які спонукають до саморозуміння за критерієм сформованості - наявність мотивів самовизначення, саморозвитку, пізнавальних мотивів;

- ставлення до себе та інших людей, де критерієм є міра вияву ціннісного ставлення, сформованість образу педагогічної діяльності та інших професійних ідеалів;

- ставлення до теоретичних знань про психологічну, фізичну і духовну природу людини i потреба у їх вдосконаленні, де критерієм сформованості $\epsilon$ наявність потреби одержувати і застосовувати знання для самовивчення;

- міра сформованості навичок саморозуміння за критерієм частоти, міри, глибини i усвідомленості їх застосування;

- наявність реалістичної самооцінки за критерієм адекватності, обов'язковості прийняття і врахування оцінки в діяльності;

- здатність до рефлексії і внутрішнього діалогу, доопрацювання, переробки і вдосконалення можливостей і здібностей; критерій - повнота, глибина, усвідомленість особистісної рефлексії, досвід внутрішнього діалогу;

- наявність професійно-педагогічного змісту в реальному та ідеальному образі “Я”, критерій наявність професійного “ідеального Я”;

- особистісний смисл педагогічної діяльності; критерій сформованості - міра представленості в саморозумінні особистості смислу педагогічної діяльності [7, 139 - 141].

Не всі показники професійного саморозуміння можуть розвиватися на етапі професійного

розв'язання педагогічних конфліктів, усвідомлення себе в педагогічному колективі, можуть виникнути та розвиватися тільки в реальній професійній діяльності.

Висновки та перспективи подальших розвідок. Саморозуміння частіше за все визначається як осягнення людиною смислу свого існування, в результаті якого відбувається когнітивне та емоційне узгодження продуктів самосвідомості та реальності. Поведінка людини співвідноситься з їі уявленнями про саму себе і 3 тим, якою вона повинна бути. Тому вивчення властивостей самосвідомості, адекватності самооцінок, структури і функцій її продуктів (“Яобразу”, “Я-концепції”) має не тільки теоретичний, але й практичний інтерес у зв'язкуз формуванням особистості та їі соціальним дозріванням.

Становлення саморозуміння - складний процес, який вимагає комплексного, системного аналізу. Тому вивчення та аналіз професійного саморозуміння майбутніх учителів вимагає застосування спеціальних методів та методик, які дають змогу з'ясувати рівень розвитку саморозуміння на різних етапах професійного становлення.

Перспективи подальших досліджень пов'язані 3 вивченням деяких структурно-динамічних характеристик саморозуміння майбутніх учителів.

\section{ЛІТЕРАТУРА}

1. Ілляш С.Д. Головні критерії і функції саморозуміння / Соломія Ілляш// Молодь і ринок. Щомісячний науково-педагогічний журнал. 2015. - № 9 (128) вересень. - С. 49-54.

2. Климов Е.А. Психология профессионального самоопределения / Е.А. Климов - Ростов-наДону: Феникс, 1996. - 512 с.

3. Коваленко А.Б. Психологія розуміння / А.Б.Коваленко - К.: Геопринт, 1999. - 184 с.

4. Луцик Д.В. Компоненти саморозуміння, їх динаміка у процесі підготовки майбутніх учителів. Науково-методичний посібник для студентів вищих педагогічних закладів освіти. / Д.В. Луцик, С.Д. Ілляш - Дрогобич: Посвіт, 2010. - 88 с.

5. Маралова Т.П. Психологические условия формирования профессиональной направленности будущих учителей / Т.П. Маралова// Психологические проблемы формирования социально активной личности учителя. - М., 1988. - C. $47-58$.

6. Маркова А.К. Психология профессионализма / А.К. Маркова - М.: Педагогика, 1996. - 256 с.

7. Протасова Н.И. Психологический анализ 
понятия "Профессиональное самопонимание учителя” / Н.И. Протасова, Б.В. Кайгородов// Мир психологии. М. - 1997. - № 1. - С. 137-141.

8. Савин Е.Ю. О подходах к исследованию и диагностике понимания / Е.Ю. Савин// Материалы II Всероссийской научной конференции по психологии РПО “Методы психологии” - Ростов-на-Дону, 1997. - Т. 3. Вып.2. - С. 233 -235.

\section{REFERENCES}

1. Illiash, S.D. (2015). Holovni kryterii i funktsii samorozuminnia [The main criteria and functions of self-understanding]. Youth and market. Monthly scientific and pedagogical magazine. No. 9 (128), pp. 49-54. [in Ukrainian].

2. Klimov, E.A. (1996). Psihologija professionalnogo samoopredelenija [Psychology of professional selfdetermination]. Rostov-na-Donu: Feniks, 512p. [in Russian].

3. Kovalenko, A.B. (1999). Psykholohiia rozuminnia [Psychology of understanding]. Kyiv: Heoprynt, 184p. [in Ukrainian].

4. Lutsyk, D.V. \& Illiash, S.D. (2010). Komponenty samorozuminnia, yikh dynamika $\mathrm{u}$ protsesi pidhotovky maibutnikh uchyteliv [Components of self-understanding, their dynamics in the process of preparing future teachers].
Scientific and methodical manual for students of higher educational institutions of education. Drohobych: Posvit, 88p. [in Ukrainian].

5. Maralova, T.P. (1988). Psihologicheskie uslovija formirovanija professionalnoj napravlennosti budushhih uchitelej [Psychological conditions for the formation of professional orientation of future teachers]. Psychological problems of formation of a socially active personality of the teacher. Moskva, pp. 47-58. [in Russian].

6. Markova, A.K. (1996). Psihologiya professionalizma [Psychology of professionalism]. Moskva: Pedagogika, 256 p. [in Russian].

7. Protasova, N.I. \& Kaygorodov, B.V. (1997). Psihologicheskiy analiz ponyatiya "Professionalnoe samoponimanie uchitelya" [Psychological analysis of the concept of "Professional teacher selfunderstanding"]. The world of psychology. No. 1, pp. 137-141. [in Russian].

8. Savin, E.Yu. (1997). O podhodah $\mathrm{k}$ issledovaniyu i diagnostike ponimaniya [On approaches to the study and diagnosis of understanding]. Materialy II Vserossiyskoy nauchnoy konferentsii po psikhologii RPO "Metody psikhologii" Proceedings of the Second All-Russian Scientific Conference on Psychology RPO "Methods of Psychology”. (pp. 233-235). Vols. 3, Rostov-naDonu. [in Russian].

Стаття надійшла до редакції 31.01.2019

\title{
G58089⿻2
}

"Ллани - ніщо, планування - все".

$$
\begin{array}{r}
\text { Dуайт Deвід Ейзенхауер } \\
\text { американський війсьқовий } і \text { державний діяч, } \\
\text { 34-й Трезидент США }
\end{array}
$$

“Будь собою, інші ролі зайняті ”.

видатний ірландський англомовний поет

\author{
"Удосконалюватися - значить мінятися, бути досқоналим - означає \\ змінюватися часто". \\ Вінстон Леонард Спенсер-Үерчилиь \\ державний діяч Великої Британї̈, писъменник
}

\begin{abstract}
"Життя оқремої людини має сенс лише тоді, коли вона допомагає зробити життя інших людей красивіше і шляхетніше".

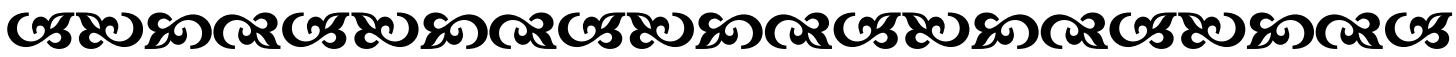

